\title{
The Need for an Effective Collaborative Production-Maintenance Approach to Improve Productivity
}

\author{
Louise Angèle Ngozag* \\ National Committee for Development of Technologies, Ministry of Scientific Research and Innovation, \\ Yaounde, Cameroon \\ National Advanced School of Engineering of Yaounde, University of Yaounde I, Cameroon \\ Laboratory of Civil Engineering and Mechanics, University of Yaounde I, Cameroon \\ Joseph Voufo \\ National Advanced School of Engineering of Yaounde, University of Yaounde I, Cameroon \\ Laboratory of Civil Engineering and Mechanics, University of Yaounde I, Cameroon \\ Florent Biyeme \\ National Advanced School of Engineering of Yaounde, University of Yaounde I, Cameroon \\ Laboratory of Civil Engineering and Mechanics, University of Yaounde I, Cameroon \\ Suila Basil Yilareng \\ National Committee for Development of Technologies, Ministry of Scientific Research and Innovation, \\ Yaounde, Cameroon \\ Lucien JR Meva'a \\ National Advanced School of Engineering of Yaounde, University of Yaounde I, Cameroon \\ Laboratory of Civil Engineering and Mechanics, University of Yaounde I, Cameroon
}

\begin{abstract}
Technological innovations, customer expectations in particular, and globalization in general have reinforced the necessity to increase productivity. There is constant market changes with decreased life cycle of products, rapid technological developments and more demanding customers. In order to improve productivity, industrial enterprises turn to either ameliorate their production or the maintenance of their equipment, parallelly with the cost function in both cases. Nonetheless, these two methods are disadvantageous because they make their neighboring function to suffer, thereby creating the inverse effects of those initially expected. Moreover, seeking to increase performance in the current industrial systems leads the integration of various services in the global management of manufacturing firms. This paper, aims to demonstrate that increasing productivity requires the interaction between the production and maintenance functions. However, this interaction must be well structured for a better efficiency. In fact, industrial productivity cannot be adequately improved if the collaborative approach, "production-maintenance", is not effective in an enterprise.
\end{abstract}

Keywords: Productivity; Production; Maintenance; Integrated Production-Maintenance Management; Production-Maintenance Cooperation.

DOI: $10.7176 /$ IEL/10-3-04

Publication date: November $30^{\text {th }} 2020$

\section{Introduction}

Faced with constantly changing markets, industrial companies must know how to take up new challenges to remain competitive. Today, small and large firms are confronted by an increasingly competitive environment, due to the internationalization of markets (Usine Nouvelle, 2016); which compels them to improve their industrial performance: profit maximization, enhance their efficiency and effectiveness, thereby improving their productivity. The concept of productivity includes the relationship between manufacturing goods and resources necessary for its realization (human, material, financial etc.), constitutes, according to Picomto (2020), one of the fundamental challenges for any competitive industrial actor. Maximizing productivity is therefore critical: a challenge that any industrial company should set, whatever the nature of its activity and the type of goods and services it produces. In this regard, how can productivity be maximized?

Among the main levers implemented for this purpose, continuous improvement undeniably occupies a preponderant status, insofar as it aims for optimal efficiency, practicability and flexibility of processes. The elimination of elements that generate inefficiency and the evolution of managerial culture are major axes (Picomto, 2020). With the aim of having an efficient production, without waste, unscheduled interruptions, unnecessary actions, at the fairest, an entire organization is thus emplaced to avoid undesirable factors which hamper productivity. The optimization of industrial process ameliorates the functions of an industrial system; meanwhile 
the involvement of industrial systems implies closed couple functions in their implementation, principally production and maintenance functions with a major "business" value. Many research works have already been carried out on ameliorating productivity by the continuous improvement of the production function or the maintenance function. In the previous cases, each function plans tasks without taking into account the activities of the other: (i) the production function assumes that machines are always available and; (ii) the maintenance function does not take into account the use of resources for production. This leads to conflicts between both functions when planning and implementing their activities using shared resources. Only few research works have been devoted to productivity improvement through the global and integrated management of production as well as maintenance functions. However, changes in business structures, management methods, and progress of problem solving inevitably lead to the cooperation between production and maintenance departments. Thus, the production maintenance cooperation is particularly interesting because these functions use the same resources. Apart from these contexts, the sophistication of the equipment and the search for an optimal use of resources in place, compel managers to incorporate maintenance activities in production so as to improve the performance of the enterprise. Based on these observations, we propose to (i) show the relationship between production-maintenance and productivity, (ii) make an inventory of research works conducted in order to increase productivity by improving the production-maintenance relationship, (iii) highlight the various types of production-maintenance cooperation by specifying their limits which adversely affect productivity growth; and (iv) conclude on the need for an effective production-maintenance cooperative approaches which corrects the limits of the previous ones.

\section{Optimization of industrial productivity}

\subsection{Process}

The main objective of a company is to produce goods and services to satisfy the demand of its clients and to maximize profits. A firm, according to Javel (2010), is part of a customer-supplier economic relationship context (the company playing alternately one or the other role).

Facing fierce competition and adapting to the emergence of new markets, enterprises have always had to mobilize human resources as one of the essential factors for their sustainability and development, i.e. a constant improvement in productivity. Deloin (2020) pointed out that in 40 years, remarkable productivity gains have been observed in the quality and costs of consumer products such as automobiles, household appliances, audio-visual, watchmaking, and IT.

Management renewal and regular changes in the industrial environment maintain the recurring need to work on industrial productivity.

However, if this objective of an overall productivity improvement is to be pursued, the evolution of the industrial organization of an enterprise should integrate the consequences of the reversal of the two components of the market, i.e. Supply and Demand.

The increase in industrial productivity is generally charaterized by:

- An improvement in the service rate;

- A reduction of customer deadline;

- A general decrease in stocks;

- An optimization of human and industrial capacities.

Increasing productivity therefore requires improving the performance of the industrial and logistic factors notably:

- 'Just-In-Time' organization ;

- Elimination of non-quality causes;

- Reduction of manufacturing times;

- Geographic and ergonomic rationalization of the factory;

- Change management.

Gain in industrial productivity is a continuous and structured approach based on the optimization of production management, particularly by "Just In Time" adoption.

Improving industrial productivity necessitates the implementation of the following three major levers which have, to be operated jointly:

- (i) dynamization of actions to improve productivity,

- (ii) optimization of transverse processes,

- (iii) mobilization and professionalization of employers.

The implementation of the dynamization of actions to improve productivity requires an initial diagnosis of the maturity of the teams of productivity improvement (where are current initiatives? Are basic productivity actions emplaced? What capacity has to be generated in order to monitor a concrete action plan?). It will then be to set up a shared portfolio of initiatives resulting from field observations, benchmarks, creativity operations (challenges, mailboxes, Hoshin method, etc.). An efficient management of this portfolio (prioritization, definition of resources and challenges, job description, support for implementation, monitoring dashboard) will guarantee a successful implementation and materialization of gains. 
Transverse cover processes cover those of support (ergonomics, quality controls, new resources, etc.) sometimes involving consumers of actor resources, which will also enable support functions (quality, methods, etc.) in these productivity efforts. Transverse processes also cover (i) collaborative processes, (ii) planning / scheduling, and (iii) organization of maintenance which are also sources of performance. Action plans must then be steered by factory management.

The mobilization and review of recognition systems must support the commitment of operators in this approach. Skills upgrading, in particular of middle management (definition and management of an action plan, animation of a Kaizen workshop, etc.) will make them sustainable.

\subsection{Research domains in productivity on the product life cycle}

Actions to increase productivity can be performed during a product life cycle. According to Vernier (1999), these actions can be done in the following domains:

- $\quad$ productivity at design ;

- $\quad$ operational productivity, and;

- productivity linked to results.

A relationship can be established between the stages of a product life cycle, actions to be taken to increase productivity, domains in which actions are taken and the events or dysfunctions that could hinder implamentation of these actions.

Table 1. Productivity research domains

\begin{tabular}{|c|c|c|c|c|c|}
\hline \multirow{6}{*}{$\begin{array}{l}\text { Life } \\
\text { cycle }\end{array}$} & Stages & Actions & $\begin{array}{c}\text { Events / } \\
\text { Dysfunctions }\end{array}$ & $\begin{array}{c}\text { Influential } \\
\text { factors }\end{array}$ & Domains \\
\hline & Design & $\begin{array}{l}\text { - Product marketing; } \\
\text { - Industrial } \\
\text { commercial plan; } \\
\text { - Industrial resources; } \\
\text { - Funding. }\end{array}$ & $\begin{array}{c}\text { - Mastery of } \\
\text { forecasts }\end{array}$ & $\begin{array}{l}\text { - Action by } \\
\text { design offices; } \\
\text { - Innovation. }\end{array}$ & $\begin{array}{l}\text { Productivity } \\
\text { at design }\end{array}$ \\
\hline & Implementation & $\begin{array}{l}\text { - Construction of means; } \\
\text { - Information system; } \\
\text { - Recruitments. }\end{array}$ & $\begin{array}{l}\text { - Delays; } \\
\text { - Unexpected } \\
\text { events; } \\
\text { - Additional } \\
\text { costs. }\end{array}$ & \multirow[t]{2}{*}{$\begin{array}{l}\text {-Action of } \\
\text { maintenance } \\
\text { and } \\
\text { production; } \\
\text {-Quality } \\
\text { assurance. }\end{array}$} & \multirow[t]{2}{*}{$\begin{array}{l}\text { Operational } \\
\text { productivity }\end{array}$} \\
\hline & Production & $\begin{array}{l}\text { - Procurement; } \\
\text { - Logistics; } \\
\text { - Manufacturing; } \\
\text { - Resources. }\end{array}$ & $\begin{array}{l}\text {-Breakdowns; } \\
\text {-Adjustments; } \\
\text { - Hazards; } \\
\text { - Delays; } \\
\text { - Change of tools; } \\
\text { - Non-quality. }\end{array}$ & & \\
\hline & Distribution & $\begin{array}{l}\text { - Marketing and } \\
\text { commercial action; } \\
\text { - After-sale support; } \\
\text { - Logistics. }\end{array}$ & $\begin{array}{l}\text { - Competition; } \\
\text {-Customer } \\
\text { satisfaction. }\end{array}$ & \multirow{2}{*}{$\begin{array}{l}\text {-Commercial } \\
\text { service; } \\
\text {-Pressure of } \\
\text { competitors; } \\
\text {-Productivity } \\
\text { efforts. }\end{array}$} & \multirow[t]{2}{*}{$\begin{array}{l}\text { Productivity } \\
\text { linked to } \\
\text { results }\end{array}$} \\
\hline & $\begin{array}{l}\text { Return on } \\
\text { investment }\end{array}$ & $\begin{array}{l}\text { - Financial receipts } \\
\text { (Takings); } \\
\text { - Margins. }\end{array}$ & - decreasing & & \\
\hline
\end{tabular}

Table 1 shows that the action of maintenance and production is the main factor influencing operational productivity. Indeed, the stages of the product life cycle that go opperational are: implementation and production. Implementation and production are close to the construction of means, information system, recruitment, supply, logistics, manufacturing and resources. Events or dysfunctions that can hinder an implementation of actions are: delays, unexpected events, additional costs, breakdowns, adjustments, contingencies, delays, tool changes, nonquality, etc. They are parameters directly linked to the management of production and maintenance as well as quality guarantee. The implementation of an efficient collaborative production-maintenance approach will enable better good control of the operating phase, thereby optimizing productivity operations.

\subsection{The influence of collaborative production-maintenance on productivity}

The traditional relationship between maintenance and production is the request for intervention, which is concretized by a work order. However, things have changed a lot. In fact, many enterprises that invested in automated machines are, theoretically capable to attain sustained production rates. Furthermore, they found out that this was not enough to meet the production targets. For the same investment, their competitors obtained higher 
outputs without always indicating exactly what was involved: maintenance, operation or design.

According to Manel (2010), the experience of many successful companies highlights the following:

- (i) an improvement of the concept of means and processes in terms of reliability between maintainability and the intrinsic efficiency of machines to increase productivity;

- (ii) the productivity of the installations of those companies, once emplaced in the production environment, is less well controlled, due to several factors more linked to organization and management of employers than technical mastery, that combine each other (Vernier, 1999).

A competition was organized in 1997 by "Usine Nouvelle and Institut Européen d'Administration des Affaires (INSEAD)", to compare the performances of fifty French and German factories. Vernier (1999) summarized the results of this competition in Table 2. These factories develop various industrial production activities.

Table 2. Comparison of productivity between French and German companies (after "Usine Nouvelle/INSEAD", $\mathrm{n}^{\circ} 2617$ of $\left.13 / 11 / 1997\right)$

\begin{tabular}{|l|c|c|c|c|}
\hline \multirow{2}{*}{} & \multicolumn{2}{|c|}{ French factories } & \multicolumn{2}{c|}{ German factories } \\
\cline { 2 - 5 } & Best & All combined & Best & All combined \\
\hline Respect of deadlines (\%) & $\mathbf{9 8 . 6}$ & 88.6 & $\mathbf{9 5 . 8}$ & 91.2 \\
\hline Duration of flow (1) (days) & 9.7 & $\mathbf{2 2 . 2}$ & 2.5 & $\mathbf{2 1 . 6}$ \\
\hline Day of finished product storage & $\mathbf{7 . 1}$ & 44.7 & $\mathbf{3 1}$ & 31 \\
\hline $\begin{array}{l}\text { Development time for a new product } \\
\text { (months) }\end{array}$ & 4 & $\mathbf{9 . 5}$ & 4 & $\mathbf{1 0}$ \\
\hline Capacity losses (2) (\%) & $\mathbf{1 0 . 4}$ & $\mathbf{1 2 . 8}$ & $\mathbf{1}$ & $\mathbf{4 . 2}$ \\
\hline $\begin{array}{l}\text { (1) Flow: raw materials, product output. } \\
\text { (2) Settings, hazards, tool changes, failures. }\end{array}$
\end{tabular}

French factories show positive performances, but also a disparity in losses of production capacity. For a saturated production line, the loss of production from one factory to another is close to $10 \%$ in turnover, which is not the case for the German enterprises.

Regarding these results, studies have been carried out on the functioning of French industrialists and the following observations could be made:

$>$ maintenance and productivity depend on multiple and combined components which do not lend to modeling and macroelement approaches practiced in France;

$>$ maintenance and production require the consideration of field information and not the opposite. Human management plays a vital role as quality circles which involve field employers in improving quality are generally a faillure in France;

$>$ only about $25 \%$ of French managers come from internal promotion. In Germany, the proportion is exactly reversed, these managers are therefore more aware of the industrial aspects that they understand other than through numbers;

$>$ the function of a maintenance manager is not rewarding in companies despite the importance of the position. It is often, in large companies, a necessary formality to get to other functions. This does not encourage creative initiatives;

$>$ French maintenance managers have fewer resources compared to their German counterparts who can commit hundreds of thousand francs for a Computerized Maintenance Management System (CMMS);

$>$ productivity actions require in depth interventions and over time, while companies are concerned with short-term results;

$>$ maintenance "quality" standards are relatively precise. However, the recent QS 9000 standards of the American automotive suppliers are much more demanding when it comes to maintenance;

$>$ all studies carried out on the effective units show a strong participation of maintenance in the search of improvement done with production, which is a basic element of Total Productive Maintenance or Top maintenance (TPM), bringing together the two businesses in a common search for improvement.

It has also been noted that the losses in production capacity are mainly due to the following causes:

- failures: dysfunctions causing production stoppage or slowing-down and requiring maintenance service. They are subject of an intervention report;

- maintenance: shutdowns to ensure scheduled maintenance (preventive, renovations, regulatory inspections, etc.);

- micro failures: minor dysfunctions (upsettings, looseness, incorrect operations, lack of ergonomics, etc.) which do not necessarily require maintenance. They are too short in duration to require an intervention report and therefore are not recorded. They currently represent 40 to $50 \%$ of malfunctionning times. Without recognized and evaluated, they are often wrongly considered as failures;

- waste products and poor quality: result from the previous causes but also by process hazards, setting defects, human errors, etc.;

- tool changes: their duration is more or less well controlled. It is often used by maintenance for 
interventions. In general, mastering tool changes goes with mastering intervention times.

Comparing theoretical production and operational capacities after a successive deduction of the different causes of losses (Vernier, 1999) (Fig. 1), it is worth noting that the degree of implication of maintenance and production services is different depending on the cause and clearly highlights the necessity of cooperation between production and maintenance units so as to optimize their capacities.

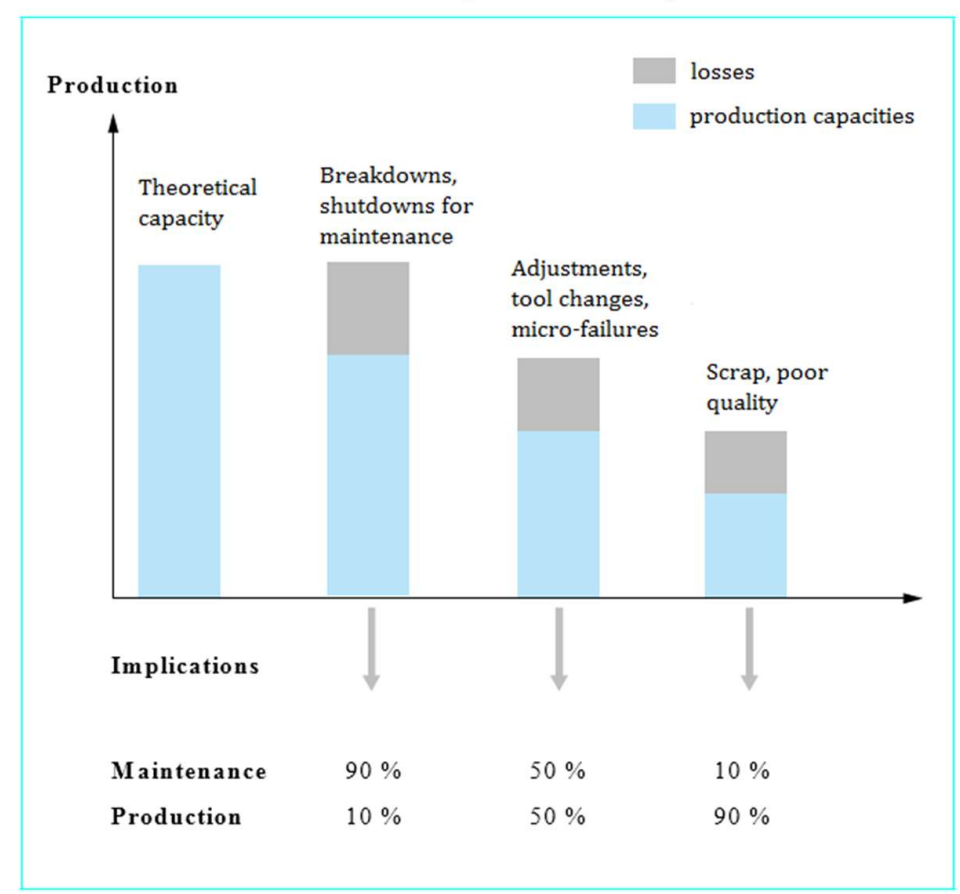

Figure 1. Causes of loss in production capacity and implication of services

Due to the lack of data, no comparative analysis was carried out on African factories, including those of Cameroon. However, statistics indicate that in global manufacturing value added, African's share remained below $1.6 \%$ during the period 1990-2014 (UNIDO, 2016). African factories in general and those of Cameroon in particular face the same difficulties, which are more than what the European firms encounter.

\subsection{Complexity of running a production system}

Running a production system in general is a complex task, as two major difficulties persist:

- First, the complexity of scheduling problems for the search of an optimal solution vis-à-vis a given criterion, without contravening the technical constraints of production system operation and attaining the objectives.

- Second, the need to obtain an optimal scheduling in a disturbed context resulting from integrating two complex and linked activities, namely production and maintenance; and which do not always have the same priority rules. Indeed, production takes into account productivity and lead time, whereas maintenance takes into account cost and efficiency. This raises the problems of interpretation and decision-making in relation with tasks or events that occur. Hence, the necessity to coordinate the different functionalities that interact in the production system operation.

The main functionalities that intervene into a production system are: the real time production system monitoring; the planning and scheduling of the various tasks; the supervision of the system; the command for specific operations, according to the state of the system; and the maintenance that ensures the durability of the production service. The interactions between these functionalities are shown in Fig. 2. 


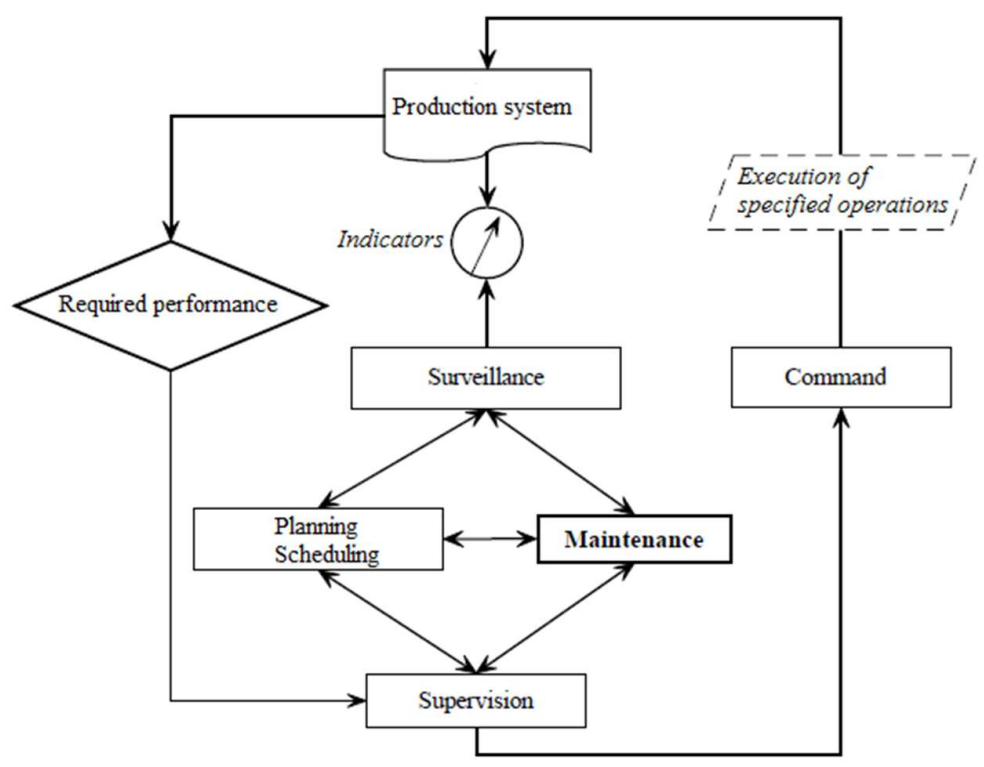

Figure 2. Maintenance in the running of a production system

This paper focuses on the mastery of the operating phase with the aim to carry out an optimal scheduling of maintenance and production interventions.

2.5. Previous works on enhancing productivity by the improvement of production-maintenance relationship Many research works have been carried out on integrated production-maintenance management:

- Talbi et al. (1997), Talbi et al. (2003) and Talbi et al. (2005) developed an approach to integrate production and maintenance tasks based on an integrated planning method. In this work, they presented the architecture of a planning system and negotiation process to be established between production and maintenance agents.

- Sassine (1998) focused on the study and integration of the maintenance function in manufacturing production systems with the aim of increasing their performance (productivity, profitability, and so on.) and improving their level of operational safety (reliability, availability, etc.) using modular modeling, based on stochastic petri networks and Markov processes, which divides the system into several elementary cells.

- Sloan and Shanthikumar (2000) developed a Markov decisional process model that simultaneously determines maintenance and production schedules for a multi-product production system with a singlemachine by taking into account that the condition of the equipment may influence differently the output of various types of products.

- Coudert (2000) focused on the contributions of multi-agent systems for negotiation in scheduling with application to production and maintenance functions.

- Coudert et al. (2001) and Coudert et al. (2004) showed how the multi-agent paradigm, often used in scheduling for its distributed aspect can provide a framework that enables the cooperation of different functions of the company in view of developing a schedule. Production and Maintenance were chosen as an example with their activities often conflicting. They suggested the use of fuzzy logic to model the temporal degrees of freedom $\left(\mathrm{L}^{\circ}\right)$ of these two functions. The authors proposed to model the production scheduling function and that of maintenance scheduling by two cooperating multi-agent systems, in order to show how the approach could enable the obtainment of a scheduling for a better compromise between the objectives of Production and Maintenance functions that are in some cases antagonistic. The concept of "collaborative approach" between production and maintenance is thus gradually initiated.

- Benbouzid et al. (2003) presented two sequential scheduling heuristics of maintenance and production in flow shop type workshops. The problem is solved in two steps: (i) schedule the production tasks with AGs and NEH algorithm and (ii) integrate the maintenance tasks based on execution order of the production tasks as strong constraint. The aim is to optimize an objective function which takes into consideration the criteria of maintenance and production at the same time.

- Kaabi et al. (2003) studied the production scheduling problem in a two-machine flow shop type industrial unit where machines can have unavailability periods due to maintenance interventions. Their optimization criterion took into consideration both maintenance and production criteria simultaneously. A heuristic 
that optimizes the chosen criterion is proposed for the resolution of scheduling problem. This heuristic has been implemented and compared with another whose aim was to place maintenance periodically without taking into account production.

- Kaabi-Harrath (2004) worked on the scheduling of systematic preventive maintenance activities in production systems. Two production systems were considered: (i) the case of a single machine and (ii) the flowshop type industrial unit. The studied optimization criterion considered production and maintenance. The author, based on a priority rule proposed by Chu and Portmann (1989) in the classic case of scheduling on a machine, proposes an algorithm by separation and evaluation allowing to generate schedules for permutation of joint problems of production and maintenance within the flowshop with two machines, and eventually an extension of the study to the case of the flowshop with several machines.

- Benbouzid Sitayeb (2005) contributed to the study of the performance and robustness of joint production / maintenance scheduling by adapting a certain number of heuristics of constructive, neighborhoods and evolutionary approaches for the case of joint scheduling production / maintenance in a permutation flowshop type workshop. They also studied the contribution of maintenance to the robustness of these joint production / maintenance schedules. It is worth noting here that it works with systematic preventive maintenance.

- Belkaid et al. (2015) considered the problem of scheduling and maintenance planning on a system of parallel machine subject to renewable and consumable resource constraints. The proposed approach based on genetic algorithms aims at reducing makespan through minimizing machines unavaibilities. The proposed model consists of simultaneously choosing for the most appropriate machine for each operation, determining the sequence of tasks assigned to the machine and defining the periods to carry out preventive maintenance.

- Bencheikh (2020) proposed a joint method of planning production and maintenance activities according to the state of production resources which varies with the use and the availability of maintenance resources, thereby emphasizing predictive maintenance. This work is an extension of the Supervisor, Customers, Environment and Producers (SCEP) planning model, a multi-agent system that allows production tasks to be planned without taking maintenance tasks into consideration.

The previous works highlight that changes in company structures, changes in management and evolution in the way of approaching problems inevitably lead to cooperation between production and maintenance services. The cooperation between production and maintenance can be initiated in three different contexts which strongly influence the outlets of advanced actions. They are:

- The production-maintenance services are uncoupled, each aiming at achieving the specific objectives which mask the overall objectives of a company;

- The production-maintenance services relationship is placed on "customer-supplier" level. In this case, each service tends to accomplish its own objectives. But, maintenance objectives are guided by production expectations;

- The two services are committed for the achievement of a common company performance objective.

\section{Discussion}

The integrated production-maintenance management highlights three main types of cooperation (see Table 3):

- The type in which production and maintenance are guided by an orderly relationship;

- The type in which production and maintenance use the same arbiter;

- The way in which production and maintenance negotiate;

\subsection{Production and maintenance governed by an orderly relationship}

Here, planning production tasks takes into consideration the existing constraints. This type of problem consists of (i) finding a schedule of maintenance interventions and then (ii) planning production tasks while respecting unavaibility constraints created by maintenance tasks. It should be noted that the maintenance system used here is mainly for corrective purposes. However, it is not always possible to know exactly when an equipment will breakedown. In fact, equipment breakedowns happen as result of their production usage. It is then impossible to estimate the breaking down time without knowing the nature and intensity of its future use. To remedy this problem, production and maintenance planning must therefore be carried out simultaneously. Hence the second type of cooperation.

\subsection{Production and maintenance use the same arbiter}

In this cooperation type, the approach consists of expressing, in the same formalism, the two problems merged in the same processing. For example, a calculation of task scheduling or resource allocation. This arbitrage concerns, among others, the conditions of intervention on production resources, a traditionally conflictual situation between production and maintenance. In this case, it is a matter of merging production and maintenance activities into the 
same schedule, with each service having constraints and degrees of freedom related to its objectives. The approach juxtaposes objectives of the two services: the decision-making frameworks are merged. The tool used is usually a scheduling engine. The problem here will be the data integration. The solution will be "optimal" but production and maintenance, constrained by this "shifted" schedule in relation to production and maintenance request, will be unsatisfied. Who will decide then? The "optimal" scheduling programme seems more suitable to start a discussion and gradually integrate the neighboring service constraints than to deliver a verdict followed directly by the services. Hence, the third type of cooperation.

\subsection{Production and maintenance negotiate}

Based on expert type compromise-seeking between production and maintenance objectives, this cooperation type corresponds to the cooperative resolution of problems. Various negotiation "logics" can be applied on the basis of multi-agent architectures that juxtapose the decision frameworks of the two services. One promising form is negotiation that alternates the relaxation of constraints between each service, alternately influencing the decisionmaking frameworks of each service. Different mechanisms of exchanging or sharing information are possible.

Each cooperation type has an area of application, specific tools and limits. Table 3 presents contexts, tools and limits of each type of cooperation.

Table 3. The three types of standard production-maintenance cooperation

\begin{tabular}{|c|c|c|c|}
\hline Cooperation type & Context & Tools & Limits \\
\hline $\begin{array}{l}\text { Production and } \\
\text { maintenance are } \\
\text { guided by } \\
\text { orderly } \\
\text { relationship }\end{array}$ & $\begin{array}{l}\text { - Maintenance decisions } \\
\text { integrate production } \\
\text { parameters: type of } \\
\text { equipment, nature of } \\
\text { manufactured products, } \\
\text { mode of funding, etc. } \\
\text { - A partnership charter } \\
\text { established between the } \\
\text { two services can be useful. }\end{array}$ & $\begin{array}{l}\text { - Implement the basic tools } \\
\text { and methods of } \\
\text { maintenance management. } \\
\text { - Over-sizing in terms of } \\
\text { resources (operators and } \\
\text { materials) for maintenance. } \\
\text { - Polyvalency of operators. } \\
\text { - CMMS supports. }\end{array}$ & $\begin{array}{l}\text { - The dominant position of } \\
\text { production tends to widen } \\
\text { the gap which separates it } \\
\text { from the maintenance } \\
\text { function. } \\
\text { - Repercussions appear on: } \\
\text { work processing requests, } \\
\text { execution of first level } \\
\text { tasks, and communication } \\
\text { and exchange of technical } \\
\text { informations for the } \\
\text { identification and } \\
\text { explanation of instructions. }\end{array}$ \\
\hline $\begin{array}{l}\text { Production and } \\
\text { maintenance use } \\
\text { the same arbiter }\end{array}$ & $\begin{array}{l}\text { Production Order }(\mathrm{PO}) \text { and } \\
\text { Work Order (WO) } \\
\text { characterized by a } \\
\text { quadruplet: } \\
\text { - start date } \mathrm{t}_{1} \text {, } \\
\text { - an ideal end date } \mathrm{t}_{2} \text {, } \\
\text { - two respective } \\
\quad \text { intervals } \mathrm{I}_{1} \text { and } \mathrm{I}_{2} \text {, } \\
\quad \text { registring dates } \mathrm{t}_{1} \text { and } \\
\quad \mathrm{t}_{2} \text {. } \\
\text { It is a RAMSES multi- } \\
\text { agent simplified model } \\
\text { common in the TPM } \\
\text { approach (work order is } \\
\text { considered as full } \\
\text { production operation). }\end{array}$ & $\begin{array}{l}\text { Arbitration is entirely } \\
\text { computerized and the tool } \\
\text { associated to the } \\
\text { corresponding processing } \\
\text { is a scheduling software. } \\
\text { Some of the difficulties } \\
\text { are: } \\
\text { - identification of } \\
\text { realistic and objective } \\
\text { parameters which } \\
\text { describe the level of } \\
\text { production and } \\
\text { maintenance } \\
\text { requirements; } \\
\text { - relative flexibility of } \\
\text { the integration of work } \\
\text { orders in terms of } \\
\text { positioning start and } \\
\text { end milestones. } \\
\text { Here, according to Ashayeri } \\
\text { et al. (1996) and Pérès et al. } \\
\text { (1997), work generally } \\
\text { considers preventive } \\
\text { maintenance interventions } \\
\text { as the performance of } \\
\text { production operations on } \\
\text { fictitious parts requiring } \\
\text { production resources. }\end{array}$ & $\begin{array}{l}\text { - The limits related to the } \\
\text { establishment of } \\
\text { arbitration. } \\
\text { - Difficulties can be due to } \\
\text { the mixing of data in the } \\
\text { same tool and } \\
\text { interpretation of results. } \\
\text { In industrial scheduling } \\
\text { softwares, production and } \\
\text { maintenance are usually } \\
\text { modeled as periods of } \\
\text { activities closure: degrees } \\
\text { of freedom that may exist } \\
\text { on their exact positioning } \\
\text { are lost. }\end{array}$ \\
\hline
\end{tabular}




\begin{tabular}{|c|c|c|c|}
\hline Cooperation type & Context & Tools & Limits \\
\hline $\begin{array}{l}\text { Production and } \\
\text { maintenance } \\
\text { negotiate }\end{array}$ & $\begin{array}{l}\text { - Co-existence of decision- } \\
\text { making strategies resulting } \\
\text { from production and } \\
\text { maintenance functions } \\
\text { which may present } \\
\text { antagonistic objectives. } \\
\text { - Functions have a certain } \\
\text { autonomy and cooperate to } \\
\text { solve problems. }\end{array}$ & $\begin{array}{l}\text { The proposal concerns the } \\
\text { exploitation of } \\
\text { organizational models } \\
\text { inspired by the concept of } \\
\text { multi-agent systems } \\
\text { developed in Distributed } \\
\text { Artificial Intelligence } \\
\text { (DAI) (Tranvouez et al., } \\
\text { 1998; Archimère and } \\
\text { Coudert, 1998). } \\
\text { It is based, according to } \\
\text { Noyes and Pérès (1999), on } \\
\text { the use of L } \mathrm{L}^{\circ} \text { of PO and } \\
\text { WO (associated with } \mathrm{I}_{1} \text { and } \\
\mathrm{I}_{2} \text { intervals of the } \\
\text { corresponding PO and } \\
\text { WO) on a PO positioning } \\
\text { to be made. Production } \\
\text { agent (P) proposes a date } \\
\text { and Maintenance agent (M) } \\
\text { checks if there is a conflict } \\
\text { with a WO positioning } \\
\text { (using } \mathrm{L}^{\circ} \text { WO). Otherwise, } \\
\text { it asks } \mathrm{P} \text { to modify the date, } \\
\text { using } \mathrm{L}^{\circ} \mathrm{PO} \text {. }\end{array}$ & $\begin{array}{l}\text { - Modeling principle and } \\
\text { formalism proposed are not } \\
\text { yet sufficiently tested in } \\
\text { this context to carry out } \\
\text { lessons. }\end{array}$ \\
\hline
\end{tabular}

By these three types of cooperation there are other types of production-maintenance cooperation within companies relating to: uncoupled services, customer-supplier relationship, and common objectives. The real situation of cooperation types between the two services is not as simple as the master-slave relations, common arbiter, and negotiation.

Given that the production function is the parent function in industrial companies, keeping the production tool in operation has always been the major concern of all managers. However, according to Cuignet (2002), they must integrate concepts on which companies are judged to be efficient or not, such as: reactivity, costs and quality. So, the merge of production and maintenance functions has become essential in terms of availability, reliability and especially productivity.

The traditional relationship between maintenance and production, which is characterized only by requests for intervention materialized by a Work Order (WO), is obsolete while the cooperation using an arbiter is proved useful but still insufficient. Nowadays, research focuses on production-maintenance cooperation negotiated type (Bencheikh, 2020). Certains authors, marking their interest to this type of cooperation, have implemented preventive maintenance (Kaabi-Harrath, 2004), while others implemented predictive maintenance (Bencheikh, 2020). With the advent of Artificial Intelligence, it would be interesting to choose production-maintenance cooperation based on predictive maintenance (Bencheikh, 2020).

\section{Conclusion}

This work shows the relationship between the production-maintenance and productivity. It makes a review of previous works carried out with the aim to improve the productivity by studying the relationship between production and maintenance, presenting the different types of production-maintenance cooperation, and specifying limits that do not promote productivity growth. It is a contribution in the process of improving productivity; with the view to show industries that we cannot talk on production amelioration of the life cycle of a product if the production-maintenance cooperation is inefficient or dose not existe. It therefore plays a sensitization role in order to encourage industries and researchers to establish an effective collaborative production-maintenance approach from the model in which production and maintenance negotiate with the aim of increasing productivity.

In industries, interconnectivity of machines, collaboration of services and transparent integration of data involve a real-time best decision-making. Industrial actors must therefore combine production and maintenance with the aim to find effective collaborations that will allow two functions emerge instead of working in improving production on one hand, and maintenance on the other hand. Productivity is closed to production and maintenance. Indeed, if the production planning is not in line with emplaced maintenance plan, productivity cannot be optimal. It is then necessary to establish an effective and efficient collaboration between production and maintenance to improve productivity. The cooperation to mature here is the type in which production and maintenance negotiate 
to obtain the objectives of the enterprise. The aim of this work was not to propose a standard effective collaborative "production-maintenance" approach, but to provide future research perspectives and show that the presence of an effective collaborative production-maintenance approach automatically leads to improvement in productivity.

Future research could be conceived to set up a new approach that will take into account the limits of the existing ones for an effective improvement. It is therefore a matter to study previous developed approaches in which production and maintenance negotiate, precisely the one developed by Bencheikh (2020) by integrating the logistics component and complex production systems; and eventually, brought in new models to be implanted in factories for observation in reframing viewpoint. The output must then be another new production-maintenance approach.

\section{REFERENCES}

Archimère, B., \& Coudert, T. (1998). A multi-agent scheduling approach for the flexible manufacturing systems. Come, Italy: IFAC Workshop on distributed computer control systems: DCCCS'98, 9-11 sep.

Ashayeri, J., Teelen, A., \& Selen, W. (1996). A production and maintenance planning model for the process industry. International Journal of Production Research, Vol.34, $\mathrm{n}^{\circ} 12,3311-3326$.

Belkaid, F., Yalaoui, F., Bennekrouf, M., \& Sari, Y. (2015). Metaheuristiques pour l'optimisation des services de maintenance et de production sous des contraintes de ressources consommables. Morroco: Xth International Conference on Integrated Design and Production, CPI.

Benbouzid Sitayeb, F. (2005). Contribution à l'étude de la performance et de la robustesse des ordonnancements conjoints production/maintenance, cas du flowshop. Thése de doctorat, Université de Franche-Comté.

Benbouzid, F., Bessadi, Y., Guebli, S. A., Varnier, C., \& Zerhouni, N. (2003). Résolution du problème de l'ordonnancement Conjoint Maintenance/Production par la stratégie séquentielle. Toulouse, France: 4éme Conférence Francophone de Modélisation et de Simulation "Organisation et Conduite d'Activités dans l'Industrie et les Services'".

Bencheikh, G. (2020). Planification conjointe des activités de production et de maintenance en fonction de l'état de santé des ressources. Thése de doctorat, Université de Toulouse.

Chu, C., \& Portmann, M. C. (1989). Minimizing total tardiness for the one-machine scheduling problem. INRIA: rapport de recherche 1023 .

Coudert, T. (2000). Apports des systèmes multi-agents pour la négociation en ordonnancement : application aux fonctions production et maintenance. Thèse de doctorat, Université INP Toulouse.

Coudert, T., Grabot, B., \& Archiméde, B. (2001). Logique floue et systèmes multi-agents pour un ordonnancement coopératif production/maintenance. Troyes, France : 3e Conférence Francophone de Modélisation et Silmulation "Conception, Analyse et Gestion des Systèmes Industriels" MOSIM'01.

Coudert, T., Grabot, B., \& Archimède, B. (2004). Systèmes multi-agents et logique floue pour un ordonnancement coopératif Production/Maintenance. Journal des Systèmes de Décision, 13(No. 1), 27-62.

Cuignet, R. (2002). Management de la maintenance. DUNOD.

Deloin, Albert, (2020), Productivité industrielle. [Online] Available: http://www.albert-deloin.fr/productiviteindustrielle.htm (2020).

Javel, G. (2010). Organisation et Gestion de la production . (4éme Edition) DUNOD.

Kaabi, J., Varnier, C., \& Zerhouni, N. (2003). Ordonnancement de la production et de la maintenance : Cas d'un atelier de type flow shop à deux machines. Valencienne, France: Colloque francophone sur les Performances et Nouvelles Technologies en Maintenance, PENTOM'03.

Kaabi-Harrath, J. (2004). Contribution à l'ordonnancement des activités de maintenance dans les systèmes de production. Thése de doctorat, Université de Franche-Comté.

Manel, B. (2010). Une approche d'évaluation et d'amélioration du service maintenance basée sur la simulation. Thése de doctorat, Univerté Hadj Lakhdar Batna.

Noyes, D., Pérès, F. (1999). Conduite intégrée de production et de maintenance dans les systèmes industriels. Montréal, Canada : Troisième Congrès International de Génie Industriel, 26-28 Mai.

Pérès, F., Caillaud, E., \& Noyes, D. (1997). La maintenance dans l'évaluation des performances des systèmes de production: une approche par la simulation. Albi, France : 2éme Congrés International Franco-Québécois "Le génie industriel dans un monde sans frontières", 3-5 sept, $n^{\circ}$ ISBN: 2-9511591-0-2.

Picomto, 2020, L'amélioration continue au service de la productivité des industries. [Online] Available: https://www.picomto.com/l-amelioration-continue-au-service-de-la-productivite-des-industries/ (2020).

Sassine, C. (1998). Intégration des politiques de maintenance dans les systèmes de production manufacturiers. Thése de doctorat, Univerté de Grenoble INPG.

Sloan, Thomas W., Shanthikumar, J. George. (2000). Combined production and maintenance scheduling for a multiple-product, single-machine production system. Production and Operations Management, 9(4), 379399.

Talbi, A., Hammouche, A., \& Tahon, C. (1997). Stratégie et modèle d'intégration de la gestion de production et 
de la maintenance industrielle. Maroc: Colloque National de Productique ' CIP2'” : la productique au service de l'entreprise.

Talbi, A., Hammouche, A., \& Tahon, C. (2003). Approche d'integration des taches production et maintenance. Valencienne, France: Colloque francophone sur les Performances et Nouvelles Technologies en Maintenance, PENTOM'03.

Talbi, A., HAMMOUCHE, A., \& Tahon, C. (2005). Methodologie d'integration des fonctions de l'entreprise : application aux fonctions production et maintenance. Oujda, Maroc: Conférence: Journées Maintenance 'JM'.

Tranvouez, E., Espinasse, B., \& Chirac, J. (1998). A multi-agent based scheduling system: co-operative and reactive approach. Nancy-Metz, France: IFAC Workshop, 9th Symposium oh information control in manufacturing, June 24-26.

UNIDO. (2016). The Role of Technology and Innovation in Inclusive and Sustainable Industrial Development. Industrial Development Report, Vienna.

Usine nouvelle, (2016), La compétitivité des entreprises industrielles portée par de nouveaux défis. [Online] Available: https://www.usinenouvelle.com/article/la-competitivite-des-entreprises-industrielles-portee-parde-nouveaux-defis.N384362 (March 21, 2016).

Vernier, J.-P. (1999). Fonction maintenance. Revue Technique de l'Ingénieur, A 8 300, 1-16. 